\title{
Access to Justice for PWDs in Civil Proceedings before the Federal Courts of Ethiopia: The Law and Practice
}

\section{Abstract}

Aschalew Ashagre*

Persons with disabilities (PWDs) are among the most vulnerable groups to social, economic and political problems. Various UN General Assembly declarations on the rights of PWDS serve as soft laws for the protection of the rights of PWDs; and the international Bill of Rights can be applicable to their protection. In particular, the UN Convention on the Rights of Persons with Disabilities (CRPD) contains provisions that recognize and protect various aspects of the rights of PWDS. The Convention clearly declares the rights of PWDs to access to justice both in civil and criminal proceedings. Ethiopia is a party to this Convention, and in effect, it has an international duty to implement, among other things, the right of access to justice for PWDs in judicial proceedings. This article examines access for PWDs in the Federal Courts in civil proceedings. It focuses on the legal and practical problems in the implementation of the right to access to justice in spite of attempts made by the government in this regard. Additional legislative and institutional improvements are thus necessary -to the extent possible- in order to realize the rights of access to justice for PWDs since substantive rights will remain meaningless in the absence of access to justice.

\section{Key terms:}

Access to justice $\cdot$ Federal courts $\cdot$ Persons with disabilities $\cdot$ Civil proceedings

DOI http://dx.doi.org/10.4314/mlr.v14i1.1

This article is licensed under a Creative Commons Attribution-

NonCommercial-NoDerivs (CC BY-NC-ND)

Received: 31 March 2020 (Version 2)

Accepted: 10 September 2020

\footnotetext{
- Aschalew Ashagre, Assistant Professor of Law, School of Law, College of Law and Governance Studies, Addis Ababa University; Consultant and Attorney at law; PhD Candidate. ORCID: https://orcid.org/0000-0002-1970-7554

I thank my research assistants Yehualsahet Tamiru and Tarekegn Damessa who helped me in distributing questionnaires and arranging focus group discussions. I also thank judges of federal courts who filled out questionnaires and gave interviews, and individuals who participated in focus group discussion.

The earlier version of this work was presented at the Third International Law and Development Conference held from September 19-22 in Leiden 2018, the Netherlands. Email: gakidan.ashagre335@gmail.com or aschalew.ashagre@aau.edu.et
} 


\section{Suggested citation:}

Aschalew Ashagre (2020), 'Access to Justice for PWDs in Civil

Proceedings before the Federal Courts of Ethiopia: The Law and Practice', 14 Mizan Law Review 1:1-30

\section{Introduction}

In order to address the multifaceted problems faced by PWDs, the international community has come up with various international instruments, both soft and binding. ${ }^{1}$ In Ethiopia, too, PWDs are vulnerable to various social and economic problems. Hence, Ethiopia has put in place some substantive laws which can be instruments for the recognition and protection of the rights of PWDs. However, the mere presence of substantive laws cannot be effective in the absence of procedural rules which ensure the special needs of PWDs in civil proceedings. Procedural rules which ensure the right of access to justice for PWDs are indispensable because various rights of these persons cannot be meaningfully enforced by courts of law where their rights are infringed. In addition to putting in place modern procedural rules, it is mandatory to establish dependable institutional frameworks which are empowered (and obliged) by law to entertain suits filed by PWDs where the latter seek enforceable remedies as a result of the infringement of their rights.

This article aims at investigating whether or not there are adequate procedural and institutional (the courts in our case) frameworks which can adequately and meaningfully ensure the right of access to justice for PWDs in civil proceedings. To this end, laws and policies are analyzed and the practice is examined by using qualitative research tools. Relevant Ethiopian laws, international conventions and declarations, and official documents of the Government of Ethiopia have been examined and analyzed. Moreover, reference is made to relevant works of Ethiopian and foreign scholars.

\footnotetext{
Acronyms

CPRD Convention on the Rights of Persons with Disabilities

GTP II The Second Growth and Transformation Plan

ICCPR International Covenant on Civil and Political Rights

PWDs Persons with disabilities

UDHR Universal Declaration of human Rights

${ }^{1}$ The United Nations and Disability: 70 Years of the Work towards a More Inclusive World, https://www.un.org/development/desa/disabilities/about-us/history-ofdisability-and-the-united-nations.html, accessed on August 17, 2020.
} 
With regard to the empirical aspect of the inquiry, interviews were conducted with five legal professionals; and questionnaires were distributed to 10 judges of the federal courts. Focus group discussion was held with PWDs of various kinds consisting of 15 persons (out of whom 10 persons have sight problems). As a consultant and attorney at law before the federal courts, the author's personal observations have also been used in the course of analysis of some of the issues.

The first section of the article briefly discusses models of disability. The second and the third sections deal with the rights of PWDs under the international and Ethiopian legal regimes respectively. The fourth section addresses the right of PWDs to access to justice in civil proceedings in Ethiopia by focusing on the legislative framework. Section 5 focuses on the analysis of the roles and responsibilities of the Federal Courts in ensuring the right of access to justice for PWDs in civil proceedings and the salient barriers that are encountered. Finally, brief concluding remarks are provided.

\section{Models of Disability: An Overview}

Models of disability are important tools for defining impairment and ultimately for providing a basis upon which government and society can devise strategy for addressing the needs of disabled people. ${ }^{2}$ In the words of Amponsah-Bediako, models of disabilities are: ${ }^{3}$

... tools for defining impairment and, ultimately, for providing a basis upon which society can devise strategies for meeting the needs of disabled people (i.e. the disabled), providing an insight into the attitudes, conceptions and prejudices of the former and how they impact on the latter. They help to reveal the ways in which society provides or limits access to work, goods and services, economic influence as well as political power for people with disabilities. The perspective from which one sees a problem determines what one does to resolve it. The perspective from which the problem is seen, or an approach to the problem, is what may be called a model.

The major models of disabilities are the charity model, the moral model, the medical model, the social model and the right-based model. According to

\footnotetext{
${ }^{2}$ Models of Disability, Michigan Disability Rights Coalition, available at http://www.copower.org/leadership/models-of-disability

${ }^{3}$ Kofi Amponsah-Bediako (2013), 'Relevance of Disability Models from the Perspective of a Developing Country: An analysis,' Developing Country Studies, Vol. 3, No. 11, p. 122.
} 
Amponash-Bediako, the charity model portrays PWDs "as victims of circumstances who deserve to be pitied." According to other authors, the charity model views PWDs as the problem and considers them as dependent on the sympathy of others who provide assistance in a charity or welfare mode. "Driven largely by emotive appeals of charity," this model is known for treating PWDs "as helpless victims of needing care and protection." This model largely relies on "the goodwill of benevolent for custodial care of the PWDs rather than justice and equality." The central tenet of this model is its perception of disability as a disqualification for claiming the right social resources which is a cause for the exclusion of PWDs from social arrangements and public services. ${ }^{7}$ Because of this, this model is seriously criticized and not influential. ${ }^{8}$

According to the moral model, "disability is viewed as a punishment inflicted upon an individual or family by an external force." It can be due to misdemeanors by the disabled person, someone in the family or community or group. This model depicts that "birth conditions can be due to actions committed in a previous reincarnation." 9 The essence and problems of this model is articulated by Deborah Kaplan in the following words: ${ }^{10}$

The moral model is historically the oldest and is less prevalent today. However, there are still many cultures that associate disability with sin and shame, and disability is often associated with feelings of guilt, even if such feelings are not overtly based in religious doctrine. For the individual with a disability, this model is particularly burdensome. This model has

${ }^{4}$ Id, p. 123.

${ }^{5}$ Shanimon.S and Rateesh K. Nair (2014), 'Theoretizing the Models of Disability Philosophical Social and Medical Concepts: An Empirical Research Based on Existing Literature', International Journal of Scientific and Research Publications,' Vol. 4, Issue 6, p. 4.

${ }^{6}$ Disability - Human Rights based model versus the Social, Medical and Charity models, Disability Junction, CUTS Centre for Consumer Action, Research \& Training (CART), 2011, available at http://www.cuts-international.org/cart/pdf/disability_junction_03-2011.pdf, p.1.

${ }^{7}$ Ibid

${ }^{8}$ Kofi Amponsah-Bediako, cited above at note 3, p.124.

${ }^{9}$ Ibid, p. 127.

${ }^{10}$ Deborah Kaplan (2000), 'The Definition of Disability: Perspective of the Disability Community', Journal of Health Care, Law and Policy, Vol. 3, p.351. See also Muradu Abdo (2014), 'Disability and the Criminal Justice System in Ethiopia,' in Pietro Toggia, Thomas F. Geraghty and Kokebe Wolde (eds.), Access to Justice in Ethiopia: Towards Inventory of Issues, Center for Human Rights, Addis Ababa University, p. 222. 
been associated with shame on the entire family that has a member with a disability. Families have hidden away the disabled family member, keeping them out of school and excluding them from any chance at having a meaningful role in society. Even in less extreme circumstances, this model has resulted in general social ostracism and self-hatred.

With the rise of the medical profession in the late $19^{\text {th }}$ and early $20^{\text {th }}$ centuries, the medical model started to assume dominant position among various views on disability. In this model, the problems associated with disability are perceived as lying solely within the individual and his or her medical condition or impairment necessitating the cure or rehabilitation of the individual with a view to fixing the defect so that the disabled person can become closer to normal. ${ }^{11}$ If one adheres to this model, one can view PWDs as weak and defective, needy and dependent and generally incapable of getting good jobs, living on their own or participating fully in society. ${ }^{12}$ In the medical model, society is not seen as having any underlying responsibility to accommodate PWDs. Instead, these persons are compelled to adapt themselves to the existing circumstances usually with the assistance of medical professionals who provide treatment and rehabilitation. ${ }^{13}$

The social model sees disability as a social construct since it is not the attribute of the individuals. According to this model, disability is created by the social environment thereby requiring social change as a primary remedy. ${ }^{14}$ This model, as explained by Michael Palmer and David Harley, asserts that impairment itself is not important; and it rather indicates that accommodations made for persons to function in society determine and, therefore, are able to ameliorate disability. ${ }^{15}$ Michael Oliver, a leading social model proponent, argues that disablement has nothing to do with body and

${ }^{11}$ Kathryn Sullivan (2011), The Prevalence of the Medical Model of Disability in Society, 2011 AHS Capstone Projects. Paper 13.

http://digitalcommons.olin.edu/ahs_capstone_2011/13, accessed on September 25, 2016, p. 3.

12 Ibid.

13 Gary C. Norman (2010), 'Re-examining Models of Disability and Applying Rationality, Morality and Ethics to Support Disability Rights in Context of Genetics.' American University Health Law and Policy, p. 21.

${ }^{14}$ Sopie Mitra (2006), 'The Capability Approach and Disability,' Journal of Disability Policy Studies, Vol. 16, No. 4, p. 237.

${ }^{15}$ Michael Palmer and David Harley, Models and Measurement in Disability: An International Review, available at http://heapol.oxfordjournals.org/content/early/2011/07/04/heapol.czr047.full, p.2. 
impairment is in fact nothing less than a description of the physical body. ${ }^{16}$ By focusing on ways in which disability is socially produced, the social model has succeeded in de-medicalizing and de-individualizing disability. As a result, the model has become an important political instrument for the empowerment and social inclusion of PWDs worldwide. ${ }^{17}$

The human rights perspective on disability is a particular aspect or part of the social model of disability. The human rights perspective within the social model gives emphasis to the natural human dignity of persons with disabilities. In the right-based model of disability, various writers agree that the notions of disability have been conceptualized as "socio-political paradigm within a rights-based discourse. Owing to this, there is a shift of emphasis from dependence since PWDs have sought political voice and become politically active against social forces of 'able-ism'."18 This emphasis accorded to human dignity indicates that the 'problem' of disability does not lie with the person with a disability. ${ }^{19}$ According to this perspective, therefore, the solution to the problem of disability must be found in the re-arrangement of the communities. As such, the state is responsible for the removal of barriers. The emphasis on human dignity in this model also requires that social and economic conditions of PWDs are taken into consideration to ensure equality of outcome. This means that this model is of particular importance to PWDs since it underscores the inclusion and accommodation of interests of these persons in relevant policies and laws of a given country. ${ }^{20}$

\section{Protection of Rights of PWDs under the International Legal Regime}

The international Bill of Rights is relevant for the protection of the substantive and procedural rights of PWDs although there are no provisions

\footnotetext{
${ }^{16}$ Ibid.

${ }^{17}$ Ibid. For further understanding of this model of disability, see Raymond Lang, The Development and Critique of The Social Model of Disability, January, 2001, available at http://www.ucl.ac.uk/lc-ccr/lccstaff/raymond lang/DEVELOPMMENT_AND_CRITIQUE_OF_THE_SOCIAL_MODEL_OF_D.p df, accessed on September 23, 2016.

${ }^{18}$ Kofi Amponsah, cited above at note 3, p. 126.

${ }^{19}$ Ilze Grobbelaar-du Plessis and Tobias van Reenen (eds.) (2011), Aspects of Disability Law in Africa, the World Bank, Washington D.C, p. xxvi.

${ }^{20}$ Ibid.
} 
Access to Justice for PWDs in Civil Proceedings before the Federal Courts of Ethiopia ... 7

which specifically address these issues. ${ }^{21}$ There have also been various declarations made by the General Assembly of the United Nations. ${ }^{22}$ However, because the rights of PWDs were "invisible elements of international human rights law," 23 the need to come up with an international convention which specifically deals with PWDs was felt by the international community. Hence, on the $13^{\text {th }}$ of December 2006, the UN General Assembly adopted the Convention on the Rights of Persons with Disabilities

${ }^{21}$ See the Universal Declaration of Human Rights, United Nations General Assembly, Paris, 10 December 1948, (General Assembly resolution 217 A, Art. 2, available at http://www.un.org/en/universal-declaration-human-rights/, accessed on September 3, 2016; International Covenant on Civil and Political Rights, (ICCPR), Adopted by the General Assembly of the United Nations on 19 December 1966 and entered into force on 23 March,1976, available at:

https://reaties.un.org/doc/publication/unts/volume\%20999/volume-999-i-14668english.pdf, accessed on September 2, 2016; International Covenant on Economic, Social and Cultural Rights (ICESCR), Adopted and opened for signature, ratification and accession by General Assembly resolution 2200A (XXI) of 16 December 1966; entry into force 3 January 1976, available at

http://www.ohchr.org/EN/ProfessionalInterest/Pages/CESCR.aspx

Accessed on September 2, 2016.

${ }^{22}$ In this regard, see the following declarations made dealing with PWDs: UN General Assembly Declaration on the Rights of Disabled Persons, General Assembly Resolution 3447 (XXX) of 9 December 1975, available at:

http://www.ohchr.org/EN/ProfessionalInterest/Pages/RightsOfDisabledPersons.aspx, accessed on September 2, 2016; UN General Assembly Declaration of Rights of Deaf-Blind Persons, (1977), available at http://hrlibrary.umn.edu/instree/deafblindrights.html, accessed on September 3, 2016; UN General Assembly World Program of Action Concerning Disabled Persons, 1982, A/RES/37/52, available at: http://www.un.org/documents/ga/res/37/a37r052.htm, accessed on September 4, 2016. For the detail of the UN Program of Action, see United Nations Decade of Disabled Persons 1983-1992 World Program of Action Concerning Disabled Persons, available at http://www.independentliving.org/files/WPACDP.pdf, accessed on September 6, 2016; UN General Assembly on the Protection of Persons with Mental Illness and the Improvement of Mental Health Care, A/RES/46/119, 75th plenary meeting, 17 December 1991, available at:

http://www.un.org/documents/ga/res/46/a46r119.htm, accessed on Sept. 4, 2016;

The Standard Rules on the Equalization of Opportunities for Persons with Disabilities, Adopted by the United Nations General Assembly, forty-eighth session, resolution 48/96, annex, of 20 December 1993, available at:

http://www.un.org/esa/socdev/enable/dissre00.htm, accessed on September 5, 2016.

${ }^{23}$ Rosemary Kayess and Philip French (2007), 'Out of Darkness into Light? Introducing the Convention on the Rights of Persons with Disabilities,' Human Rights Law Review, p. 13. 
$(\mathrm{CRPD})^{24}$ and an optional protocol. ${ }^{25}$ This Convention is the first UN human rights treaty which was reputed to be rapidly negotiated. ${ }^{26}$ The Convention was also received by the international community with unprecedented early enthusiasm. It was signed by 81 countries and the European Union at its opening ceremony held on the $30^{\text {th }}$ of March, 2007. ${ }^{27}$

The Convention establishes a comprehensive framework to protect and promote the rights of PWDs. ${ }^{28}$ It represents a shift in approach to PWDs at the international policy level. ${ }^{29}$ Rather than perceiving PWDs as objects of charity, medical treatment and social protection, it recognizes them as holders of rights. ${ }^{30}$ To this end, the Convention has recognized that PWDs hold every civil, cultural, economic, political and social right, on equal basis with others. In order to ensure equality before the law, the Convention forbids discrimination on the basis of disability whether in laws, regulations,

${ }^{24}$ Convention on the Rights of Persons with Disabilities, adopted by the UN General Assembly on the $13^{\text {th }}$ of December 2006, signed on the $30^{\text {th }}$ of March 2007 and entered into force on May 3, 2008, available at http://www.un.org/disabilities/documents/convention/convoptprot-e.pdf, accessed on August 3, 2019.

${ }^{25}$ See Optional Protocol to the Convention on the Rights of Persons with Disabilities, available at https://www.ohchr.org/EN/HRBodies/CRPD/Pages/OptionalProtocolRightsPersonsW ithDisabilities.aspx, accessed on October 17, 2020.

${ }^{26}$ The CRPD, cited above at note 24, p. 2. See also Secretary-General Hails Adoption of Landmark Convention on Rights of People with Disabilities, SG/SM/10797HR/4911-L/T/4400, 13 December, 2006, available at: http://www.un.org/press/en/2006/sgsm10797.doc.htm, accessed on October 1, 2016.

${ }^{27}$ Rosemary Kayess and Philip French, cited above at note 23, p. 2.

${ }^{28}$ Arlene S. Kanter (2009), 'The United Nations Convention on the Rights of Persons with Disabilities and its Implications for the Rights of Elderly People under International Law,' Georgia State University Law Review, Vol.25, Issue 3, p. 527.

${ }^{29}$ See 'Including the Rights of Persons with Disabilities in United Nations Programming at country level, A Guidance Note for United Nations Country Teams and Implementing Partners, United Nations Development Group,' available at: http://www.un.org/disabilities/documents/iasg/undg_guidance_note_final.pdf, accessed on September 3, 2016, p. 15. See also Ron McCallum, 'The United Nations Convention on the Rights of Persons with Disabilities: Some Reflections,' Legal Studies Research Paper No. 10, 30 March 2010, Sydney Law School, the University of Sydney, available at http://www.disabilityaction.org/fs/doc/publications/the-unitednations-convention-on-the-rights-of-persons-with-disabilities-professor-ronmccallum.pdf, accessed on September 15, 2016.

${ }^{30} \mathrm{Ibid}$, (the guidance note.) 
customs and practices. ${ }^{31}$ In order to eliminate discrimination, the Convention compels states parties to ensure the full realization of all human rights and fundamental freedoms for PWDs by taking all appropriate measures. ${ }^{32}$

The Convention has given recognition to both substantive equality and equality of results with a view to promoting the equality of PWDs in all areas of life. ${ }^{33}$ To eliminate discrimination, states are duty-bound to provide reasonable accommodation ${ }^{34}$ which consists of the modifications or adjustments that are necessary and reasonable in a particular case with the purpose of ensuring that PWDs are able to exercise certain rights. ${ }^{35}$ States Parties to the Convention are also required to take specific measures that are instrumental to promote equality. ${ }^{36}$ The Convention embodies eight fundamental principles: respect for inherent dignity, individual autonomy and independence of persons, non-discrimination, full and effective participation and inclusion in society, respect for difference, equality of opportunity, accessibility, equality between men and women and respect for evolving capacity of children. ${ }^{37}$

Furthermore, the Convention compels states parties to incorporate disability sensitive measures into the mainstream service delivery and to provide services which are specific to disability in order to support the inclusive and participation of PWDs. Under the Convention, PWDs are entitled to accessibility to the physical environment, to transportation, to information and communication technologies and systems. ${ }^{38}$ The Convention is also praiseworthy because of its categorical recognition of the right of access to justice for PWDs which is an important tool for the implementation of the substantive rights recognized in the Convention. ${ }^{39}$ The Convention is indeed applauded because it has set out arrangements for its implementation and monitoring at national and international levels. ${ }^{40}$

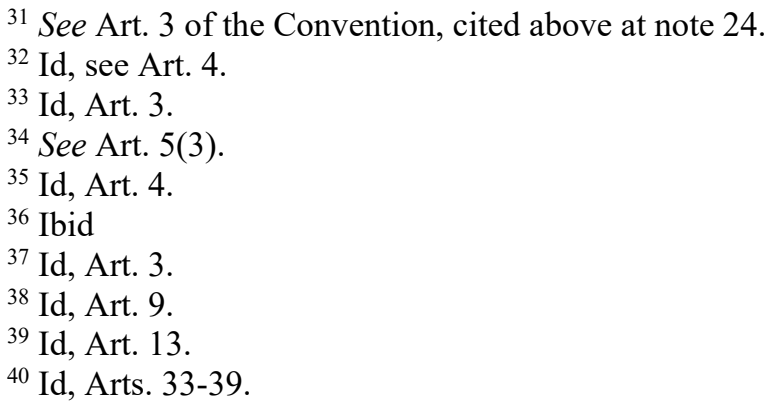




\section{Protection of the Rights of PWDs under the Ethiopian Legal Regime}

Ethiopia came up with a written constitution in 1931 which contained few provisions concerning the protection of human rights subject to the suspension of these rights by the Emperor who had an absolute power. ${ }^{41}$ The 1931 Constitution was revised in 1955 embodying several human rights provisions. ${ }^{42}$ However, the latter did not contain any provision concerning the protection of rights of PWDs despite the inclusion of an equality clause. $^{43}$

The 1971 Imperial order was the first legislation in Ethiopia which tried to touch upon the rights of PWDs although it was entirely dependent upon the charity model of disability. ${ }^{44}$ Another law, issued during the imperial regime is the 1960 Civil Code of Ethiopia which under its Art. 340 states that "deaf-mute, blind persons, who as a consequence of permanent infirmity are not capable to take care of themselves or to administer their property may invoke in their favor the provisions of the law which afford protection to those who are insane." 45

During the Dergue Regime, Art. 22 of the Constitution of the People's Democratic Republic of Ethiopia (the PDRE Constitution) ${ }^{46}$ stated that "the state and society shall provide special care for those disabled in the course of defending the sovereignty and territorial integrity of Ethiopia and safeguarding the revolution as well as the families of the martyrs." ${ }^{.47}$ This

${ }^{41}$ See the 1931 Constitution of Ethiopia, Arts.22-29, available at http://www.rastafari.com/documents/EN_Ethiopian_Constitution_1931.pdf, accessed on October 5, 2016. See also Adem Kasie (2011), 'Human Rights under the Ethiopian Constitution: A Descriptive Overview,' Mizan Law Review, Vol. 5, No 1, p.1.

${ }^{42}$ See The Revised Constitution of the Empire of Ethiopia, Proc. No 149/ 1955, Nega. Gaz., Year 15, No 2, Arts. 37-61.

${ }^{43} \mathrm{Ibid}$, Arts. 37 and 38 of the Constitution are relevant in this regard because the former stated about equality before the law and the latter stated non-discrimination.

${ }^{44}$ See Order of Establishment of the Rehabilitation Agency for Disabled, Proc. No. 70/1971, Neg. Gaz., Year 15, No. 2. See also Muradu Abdo, cited above at note 10, p. 222.

45 The Civil Code of the Empire of Ethiopia, Proc. No 165/1960, Neg. Gaz., Year 19, No 2.

46 See the Constitution of People's Democratic Republic of Ethiopia, Proc. No1/1987, Neg. Gaz., Year 47, No. 1.

47 This means that this constitutional provision was confined to the medical-charity models and the protection was available only to those persons who became disabled 
Access to Justice for PWDs in Civil Proceedings before the Federal Courts of Ethiopia ... 11

provision clearly demonstrates that it was not every disabled person and his/her family that would benefit from the above cited provision of the PDRE Constitution. Rather, it was only those who became disabled persons as a result of the war to defend the country who would benefit from the above constitutional provision.

This means that the approach of the PDRE Constitution was discriminatory. Moreover, the PDRE Constitution did not give recognition to the social model or the human rights based model to protect the rights of PWDs. Rather the constitution pursued the charity model since it did not require the state and the society to make the environment as accommodative as possible but to provide care to the disabled and the family of the martyrs. ${ }^{48}$

The 1991 Transitional Period Charter declared that fundamental rights and freedoms recognized under the Universal Declaration of Human Rights (UDHR) were accepted under the Charter. ${ }^{49}$ Therefore, because the UDHR contains a provision which can be invoked in support of the equal protection of the rights of PWDs, discrimination against PWDs could not be possible during the transition period. The legislation specifically relating to PWDs during the transition period was the Rights of Disabled Persons to Employment Proclamation which was promulgated in 1994. ${ }^{50}$

The 1995 FDRE Constitution clearly incorporates the equality clause which prohibits discrimination on the basis of any status. ${ }^{51}$ The Constitution further provides that all international instruments "ratified by Ethiopia are an integral part of the law of the land" 52 and the provisions of the Constitution that deal with fundamental rights and freedoms shall to be interpreted in conformity with international human rights instruments to which Ethiopia is

in the course of defending the motherland and the revolution to the exclusion of other disabled persons.

${ }^{48}$ In this regard, see Dawit Oticho, The Place of the Rights of Persons with Disabilities under the 1995 FDRE Constitution, A Thesis Submitted in Partial Fulfillment of the Degree of Master of Laws (LLM in Human Rights Law) to the School of Law, January 2019, available at http://etd.aau.edu.et/handle/123456789/19177, accessed on December 28, 2019, pp. 37-38.

49 Transitional Period Charter of Ethiopia, 1991, Neg. Gaz., Year 50, No 1, July 1991.

50 The Rights of Disabled Persons to Employment Proclamation, Proc.101/1994, Neg. Gaz., Year 53.

${ }^{51}$ The Constitution of the Federal Democratic Republic of Ethiopia, Proc. No 1/ 1995, Fed. Neg. Gaz., Year 1, No., Art. 25.

${ }^{52}$ Id, Art. 9(4). 
a party. ${ }^{53}$ Moreover, Art. 41(5) of the Constitution stipulates that "the state shall allocate resources to provide rehabilitation and assistance to the physically and mentally disabled."

Two points are worthy of emphasis here. First, the FDRE Constitution is heavily influenced by the medical-charity models of disability since its concern is confined to rehabilitation and assistance. Secondly, the Constitution does not contain specific provisions which can directly be invoked concerning the protection of rights PWDs. Thus the FDRE Constitution, same as the provisions of the core international human rights instruments, does not have specific provisions dealing with the rights of PWDs.

The 2002 VAT and Turnover Tax Proclamations have also some relevance to enhance the rights of PWDs. ${ }^{54}$ Another law relevant to the protection of the rights of PWDs is the Right to Employment of Persons with Disabilities Proclamation, enacted in 2008. ${ }^{55}$ This proclamation has directly addressed the employment rights of PWDs by incorporating the most important values of the CRPD. ${ }^{56}$ The Proclamation embodies the human rights and the social models of disability that vary from the charity and medical models. 57

One of the core concerns relating to the rights of PWDs is physical accessibility of facilities and services which is very crucial, and laws that ensure accessibility are indispensable. ${ }^{58}$ In this regard, the Federal Building Proclamation $^{59}$ provides that, "any public building is required to have a means of access suitable for use by physically impaired persons, including those who are compelled to use wheelchairs and those who are able to walk

${ }^{53}$ Id, Art. 13(2).

${ }^{54}$ Under these two proclamations it has been provided that the supply of goods or services by a workshop employing more than $60 \%$ disabled individuals is an exempt transaction which is beneficial to disabled persons.

55 The Right to Employment of Persons with Disabilities Proclamation, proc. No. 568/2008, Fed. Neg. Gaz., Year 14, No. 20.

56 See Seyoum Yohannes (2010), 'Towards Inclusive Employment: The Conceptual Basis and Features of Proclamation 568/2008 on the Employment of Persons with Disabilities,' Journal of Ethiopian Law, Vol. 24, No. 1.

57 See Muradu Abdo, cited above at note 10, p. 236; Shimelis Ashagre, (2014), 'Appraising Employment Rights for Visually Impaired Teachers in Ethiopia: Overview of Selected Cities,' Mizan Law Review, Vol. 8, No 2, p. 407.

${ }^{58}$ See the CRPD, cited above at note 24, Art. 9.

${ }^{59}$ Ethiopian Building Proclamation, Proc. No. 624/2009, Fed. Neg . Gaz., Year 15 , No. 31. 
Access to Justice for PWDs in Civil Proceedings before the Federal Courts of Ethiopia ... 13

but unable to negotiate." ${ }^{\circ 0}$ This Proclamation states that "where toilet facilities are required in any building, as adequate number of such facilities must be suitable for use by physically impaired persons and must be accessible to them." ${ }^{61}$ Yet, the scope of accessibility provided in the Proclamation is narrow because accessibility in connection with buildings is wider than what the law has provided.

A building regulation ${ }^{62}$ was issued by the Council of Ministers for the proper implementation of the Building Proclamation in 2011. This regulation contains relatively detailed provisions which would enhance accessibility of buildings to PWDs in general. The regulation is applicable to any public building, and it is also binding on higher education institutions. Art. 34(1) of the Regulation clearly stipulates that "any public building or part thereof must not prevent or hinder the movement of disabled persons." Art. 34(2) of the same Regulation states that "suitability for persons with disability is one of the criteria to be considered in giving an occupancy permit for partially completed public building."

Most importantly, Art. 34(4) stipulates that "international standard signs must be posted at junctions to keep persons with disabilities from any obstacles and to indicate parking lots allocated for them." ${ }^{63}$ In addition to the Proclamation and the Regulation, a building directive was issued in May 2011 by the then Ministry of Urban Development and Construction. ${ }^{64}$ The directive contains provisions which are instrumental to ensure accessibility and suitability of buildings to PWDs. Art. 33 of the Directive contains detailed sub-articles that require accessibility of buildings to PWDs which embody strict requirements to be fulfilled when stairs, rumps, gates, doors and parking lots are constructed.

${ }^{60} \mathrm{Id}$, Art. 36(1)

${ }^{61} \mathrm{Id}$, Art. 36(2)

${ }^{62}$ Council of Ministers Building Regulation, Reg. No. 243/2011, Fed. Neg. Gaz., Year 17, No. 71.

${ }^{63}$ There is discrepancy between the Amharic and English versions of Art. 36 of the Proclamation and Art. 34 the Regulation. The scope of application of the English version is limited to public buildings while the Amharic version covers all buildings which are destined to public use. The Amharic version, which is the binding version, is thus better than the English version in the protection of the rights of PWDs.

${ }^{64}$ Building Directive, Directive Number 5/2011. 
Art. 41 of the Higher Education Proclamation ${ }^{65}$ enacted in 2019 -to a certain extent- ensures the right of students with disabilities to inclusive education. Art. 41(1) states that "higher education institutions are obliged to, to the extent possible, make their facilities and programs amicable to use with relative ease by students with physical disabilities." And, Art. 41(2) requires higher education institutions to "relocate classes, develop alternative testing procedures and provide educational auxiliary aids in the interest of students with disabilities and learning disabilities." However, higher education institutions are required to discharge such obligations to the extent that situations and resources permit.

The Proclamation requires higher education institutions to make sure that building designs, campus physical landscape, computers and other infrastructure take into account the interests of PWDs. ${ }^{66}$ The Proclamation further states the duty of higher education institutions "to ensure that students with physical challenges get academic assistance including tutorial sessions, exam time and submission deadline extensions." ${ }^{.67}$ The Ethiopian Electoral law also addresses the special needs of PWDs in their capacity as voters or candidates in elections. ${ }^{68}$ In particular, the CRPD, ratified by Ethiopia in July $2010,{ }^{69}$ is the most important legal instrument ${ }^{70}$ because its ratification renders it an integral part of the laws of Ethiopia by virtue of Art. 9(4) of the FDRE Constitution.

\section{Overview of Access to Justice for PWDs in Civil Proceedings}

\subsection{Access to justice in general}

The civil justice system requires adequate attention from policy makers and law-makers since it is "a public good that serves much more than private

${ }^{65}$ Higher Education Proclamation, Proc. No.1152/2019, Fed. Neg. Gaz., Year 25, No. 78.

${ }^{66}$ Id, Art. 40(3).

${ }^{67} \mathrm{Id}$, Art. 40(4).

${ }^{68}$ The Ethiopian Electoral, Political Parties Registration and Election's Code of Conduct Proclamation No.1162/2019, Fed. Neg. Gaz., Year 25, No.97, Arts. 22(7), 32(2) \& 52.

${ }^{69}$ Convention on the Rights of Persons with Disability Ratification Proclamation, Proclamation No. 676/2010, Fed. Neg. Gaz. Year 16, No. 32.

${ }^{70} \mathrm{CPRD}$ is a comprehensive international legal instrument containing praiseworthy substantive and procedural provisions on the rights of PWDs. 
Access to Justice for PWDs in Civil Proceedings before the Federal Courts of Ethiopia ... 15

interests." T1 The term 'civil justice' is used in different ways with overlapping meanings. Some authors use the term as a synonym for the civil portion of the legal system in contradistinction to the body of law that constitutes the criminal justice system. ${ }^{72}$ Other scholars use the term as some sort of ideal for how the legal system, other than the criminal justice system, should function, while still others argue that civil justice simply refers to civil litigation. However, the scope of civil justice goes far beyond civil litigation. ${ }^{73}$ In real terms, the definition of civil justice includes not only the substantive law affecting civil rights but also the machinery provided by the state and the judiciary for the purpose of resolution of civil disputes and grievances. $^{74}$

The administration of civil justice involves "the institutional architecture, the procedures and apparatus" used to process, adjudicate and ultimately decide civil disputes. ${ }^{75}$ Associated with the nature of civil justice are civil procedural rules which are instruments for the implementation rights that are recognized and protected under substantive laws. In other words, procedural rules are "the means by which society expresses its underlying meaning.",76 This conclusion applies to every individual who is engaged in civil proceedings since access to civil justice is unthinkable in the absence of fair procedural rules.

Writers underscore that the concept of access to justice is an elusive term since it is used in reference to various mechanisms through which an individual may seek legal assistance. ${ }^{77}$ According to a committee established

${ }^{71}$ Hazel Genn, (2012), 'What Is Civil Justice for? Reform, ADR, and Access to Justice,' Yale Journal of Law and the Humanities, Vol. 24, Issue No 1, PP.397-398.

${ }^{72}$ Jason M. Solomon (2010), 'What is Civil Justice?', Faculty Publications, Paper 1149, available at http://scholarship.law.wm.edu/facpubs/1149, accessed on October 5, 2016, pp. 319-324.

${ }^{73}$ Ibid.

${ }^{74}$ Ibid.

${ }^{75}$ See Hezel Genn (2010), Judging Civil Justice, Cambridge University Press, pp. 1724.

${ }^{76}$ Ibid.

${ }^{77}$ For analysis on the problems of defining access to justice, see Bedner, A. \& Vel, J.A.C., (2010), 'An Analytical Framework for Empirical Research on Access to Justice', Law, Social Justice \& Global Development Journal, Electronic Journal, No 1 , available at https://www2.warwick.ac.uk/fac/soc/law/elj/lgd/2010_1/bedner_vel/bedner_vel.pdf, accessed on October 13, 2016. 
by the Common Wealth Government (Australia) in $1994,{ }^{78}$ the concept of access to justice involves three key elements. These are: quality of access to legal services ensuring that all persons have access to high quality legal services or effective dispute resolution mechanisms necessary to protect their rights and interests, national equity -ensuring that all persons enjoy, as nearly as possible, equal access to legal services and equality before the law- ensuring the all persons, regardless of race, ethnic origins, gender or disability, are entitled to equal opportunities to access to legal services.

The term is used predominantly to refer to access to judicial remedies to protect rights which have received legal recognition. Access to justice is associated with procedural elements such as access to courts, the right to fair hearing, access to legal services, adequate redress and the like. ${ }^{79}$ However, modern reformers and commentators on access to justice use the broader concept of access to justice which is even concerned with the substantive aspect of justice -"the use of the legal system as a tool to achieve overall social justice." $" 80$

\subsection{The CRPD as an integral part of the law of the land}

As indicated earlier, the Convention is meant to promote, protect and ensure the full and equal enjoyment of all human rights and fundamental freedoms by all PWDs, and to promote respect for their inherent dignity. However, in the absence of the right to access to justice, these rights and freedoms cannot be attained, and PWDs cannot invoke the Convention in their own countries if they do not have access to justice. ${ }^{81}$ Art. 13 of the Convention is devoted to access to justice of PWDs, and it provides:

1. States parties shall ensure effective access to justice for persons with disabilities in equal basis with others, including through the provision of procedural and age appropriate accommodations, in

${ }^{78}$ See Sarah Ellison, Louis Schetzer, Joanna Mullins, Julia Perry and Katrina Wong (2004,), Access to Justice and Legal Needs, Vol. 1, Law And Justice Foundation of New South Wales, available at http://www.lawfoundation.net.au/ljf/site/articleids/6ffeb98d3c8d21f1ca25707e0024d3 eb/\$file/older_law_report.pdf, accessed on September 15, 2016, p. 8.

${ }^{79}$ Kokebe Wolde (2014), 'Rethinking Access to Justice in Ethiopia: Towards Human Rights Based Approach,' in Pietro Toggia, Thomas F. Geraghty and Kokebe Wolde (eds.), Access to Justice in Ethiopia: Towards Inventory of Issues, Center for Human Rights, Addis Ababa University, p. 14.

${ }^{80}$ Ibid.

${ }^{81}$ Kevin M. Cremin (2016), 'What Does Access to Justice Require? -Overcoming Barriers to Invoke the United Nations Convention on the Rights of Persons with Disabilities,' Frontiers of Law in China, Vol. 11, No 2, p. 281. 
order to facilitate their effective role as direct and indirect participants, including as a witness, in all legal proceedings, including at investigative and other preliminary stages.

2. In order to help ensure effective access to justice for persons with disabilities, states parties shall promote appropriate training for those working in the field of administration of justice, including police and prison staff.

Article 13(1) consists of three main elements. First, it embodies the qualifier "effective." The second element is that access to justice for PWDs must be on equal basis with others. Third, it demonstrates some of the things that must be done by a state party to the Convention with a view to ensuring effective access to justice. It is to be noted that the list is not exhaustive, and focuses on the need to make procedural and age-appropriate accommodations aiming at ensuring participation by PWDs at all stages of legal proceedings.

The Convention was ratified by Ethiopia in July 2010 and has become an integral part of Ethiopian law thereby enabling individuals who are beneficiaries of the Convention to invoke its provisions as though they were embodied in any domestic legislation. ${ }^{82}$ Ethiopian courts are thus dutybound to apply the provisions of this Convention. Yet, as Art. 13 of the Convention is brief, it cannot be an adequate tool for the full realization of the right of access to justice for PWDs unless it is supplemented by a domestic legislation which contains detailed provisions concerning access to justice in civil proceedings.

\subsection{The FDRE Constitution and the Civil Procedure Code}

In Ethiopia, access to justice is a fundamental human right which is recognized under Art. 37 of the FDRE Constitution ${ }^{83}$ which is the supreme law of the land. Although there is no special mention of the right of access to justice of PWDs in the Constitution, Art. 37 applies to any individual, including PWDs, who submits a justiciable matter to courts or other tribunals recognized by law. However, Art. 37 of the Constitution is a general provision, and it cannot adequately guarantee the right to access to justice of PWDs without a particular legislation which would be instrumental to ensure the right of PWDs to access to justice in civil

\footnotetext{
${ }^{82}$ See Art. 9(4) of the FDRE Constitution, cited above at note 51.

${ }^{83} \mathrm{Id}$, Art. 37.
} 
proceedings. The 1965 Civil Procedure Code $^{84}$ applies to all civil proceedings. The question, however, is whether the 1965 Civil Procedure Code contains procedural rules that are capable of realizing the right of access to justice of PWDs.

As Hezel Genn notes, the civil justice system cannot be fully understood and meaningful in the absence of civil procedure and that is why procedural rules are the main targets of civil justice reformers. She states that a critical challenge in solving the problem of cost, complexity and delay in civil justice is that of getting the rules right. ${ }^{85}$ It has been submitted that the nature and quality of a legal regime is revealed not only through substantive laws but also through clearly formulated procedural laws. According to Jeremy Bentham, the rules of procedure occupy the central place in civil justice administration since the power of procedure is in the link between evidence and correct decisions. ${ }^{86}$ Robert Allen Sedler also underscored that the system of procedure is designed to make sure that judges have all the relevant evidence available for the purpose of finding the material facts and apply the substantive law to those facts. In short, procedure is the means by which substantive rights are enforced. ${ }^{87}$

In Ethiopia, due emphasis was not given to procedure before the 1940s. The need to have modern procedural rules was felt starting from the 1940's and in 1965 the current Civil Procedure Code was adopted as an imperial decree. ${ }^{88}$ According to Aberra Jembere, the basic text of the Code was drafted by the Codification Department of the then Ministry of Justice (currently Federal Attorney General). The Code contains the practices that existed during the time although many of its provisions were based on the principles contained in other codes such as the Indian Code of Civil Procedure. ${ }^{89}$

Even though the Civil Procedure Code has many useful provisions for the proper administration of civil justice, it is fraught with a number of problems that are source of hindrance to dispose civil cases effectively, economically

${ }^{84}$ The Civil Procedure Code of the Empire of Ethiopia of 1965, Decree No.52/1965, Neg. Gaz., Year 25, No. 3.

${ }^{85}$ Hezel Genn, cited above at note 75, p. 13.

${ }^{86}$ Ibid.

87 See Robert Allen Sedler (1968), The Ethiopian Civil Procedure, Faculty of Law, Haile Sellasie I University in association with Oxford University Press, p. 1.

${ }^{88}$ Ibid, p. 3.

89 Abera Jembere (2012), An Introduction to the Law History of Ethiopia: 1434-1974, Shama Books, Addis Ababa, Ethiopia, P. 208. 
Access to Justice for PWDs in Civil Proceedings before the Federal Courts of Ethiopia ... 19

and expeditiously. ${ }^{90}$ The Civil Procedure Code does not embody provisions which are sensitive to the right of access to justice for PWDs. This problem may, in the main, be attributable to the fact that the idea of protection of the rights of PWDs in general -and access to justice of these persons in particular- was alien to the Ethiopian legal system at the time of the Code's promulgation in $1965 .^{91}$

Currently, it is not possible to enhance the rights of access to justice of PWDs in civil proceedings by using the provisions of the 1965 Civil Procedure Code. The law-maker in Ethiopia, which has the highest political authority as per the FDRE Constitution, ${ }^{92}$ has not yet discharged its legislative duty with regard to the issue under consideration. The legislative organ does not also seem to have plans to revise the Code in the foreseeable future. ${ }^{93}$ Indeed, it is high time for Ethiopia to revise its Civil Procedure Code and incorporate procedural rules that will be instrumental to realize access to justice for PWDs.

\section{The FDRE Courts and the Right of PWDs to Access to Justice in Civil Proceedings}

\subsection{An overview of the FDRE courts}

Judicial power in Ethiopia is divided between the Federal Government and the federating units. ${ }^{94}$ The Constitution states that supreme judicial authority over federal matters is vested in the Federal Supreme Court ${ }^{95}$ while supreme judicial authority over regional matters is vested in regional supreme courts. ${ }^{96}$ The Constitution also provides for delegated jurisdiction of the

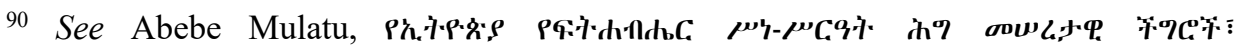

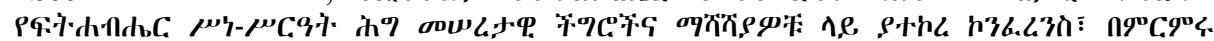

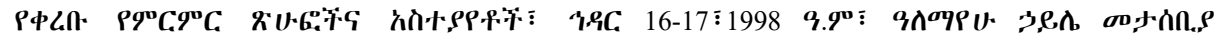
P.C.

${ }^{91}$ At that time, we had no substantive law which would guarantee the substantive rights of PWDs in all respects and hence the need to have procedural rules addressing the right to access to justice of PWDs was not totally felt for that would be putting the cart before the horse.

92 FDRE Constitution, cited above at note 51, Art. 50.

${ }^{93}$ Opening speech made by the President of the Republic to the joint session of the House of People's Representatives and the House of Federation.

${ }^{94}$ See the FDRE Constitution, cited above at note 51, Art. 50.

95 Id, Art. 80(1).

${ }^{96}$ Id, Art. 80(2). 
Federal High Court and the First Instance Court that can be delegated to the states courts i.e. to the state supreme courts and high courts respectively. ${ }^{97}$

Decisions rendered by the state supreme court on federal matters are appealable to the Federal Supreme Court while decisions rendered by the State High Court exercising the jurisdiction of the Federal First Instance Court are appealable to the State Supreme Court since the power of the State Supreme Court is assumed to be equivalent to the power of the Federal High Court. ${ }^{98}$ The 1996 Federal Courts Proclamation which is still in force with some amendments ${ }^{99}$ states the judicial power of the federal courts ${ }^{100}$ and their material jurisdiction. ${ }^{101}$

\subsection{Roles and responsibilities of the FDRE courts}

Needless to say, courts of law play irreplaceable roles in protecting fundamental rights of all persons in general $^{102}$ and PWDs in particular

${ }^{97}$ Id, Art. 80 (2 and 4).

${ }^{98} \mathrm{Id}$, Art. 80 (5 and 6).

${ }^{99}$ Federal Courts Proclamation, Federal Courts Proclamation (as amended), Proc. No 25/1996, Fed. Neg. Gaz., Year 2, No. 13.

${ }^{100}$ Ibid; by virtue of Art. 5 of the Federal Courts Proclamation, the federal courts have jurisdiction on cases to which the federal government is a party, suits between persons permanently residing in different regions, cases regarding liability of officials or employees of the Federal Government in connection with their official responsibilities or duties, cases to which a foreign national's a party, suits involving matters of nationality, suits regarding negotiable instruments, suits relating to patent, literary and artistic ownership rights, suits regarding insurance policy application for habeas corpus.

${ }^{101}$ As far as the material jurisdiction of the three tiers of the federal courts is concerned, Arts. 8, 11 and 14 of the same Proclamation are relevant. Art. 8 of the Proclamation indicates that the Federal Supreme Court does not have first instance jurisdiction in civil cases except entertaining an application for change of venue which means that the federal Supreme Court accepts and entertains civil cases in appellate and cassation proceedings as can be observed from the reading of Arts. 9 and 10 of the Proclamation respectively. Articles 11 and 14 of the Proclamation respectively state the material jurisdiction of the Federal High Court and the Federal First Instance Court.

102 See Fahed Abul-Ethem (2003), 'The Role of the Judiciary in the Protection of Human Rights and Development: A Middle Eastern Perspective,' Fordham International Law Journal, Vol. 26, Issue 3; see also Ambika Pant, Role of Courts in Protection of Human Rights, available at http://ujala.uk.gov.in/files/issue\%202/2Ch5.pdf, accessed on October 3, 2016; Oagile B.K. Dingake, The Role of the Judiciary and the Legal Profession in Protecting the Rights of 18 Vulnerable Groups in Botswana, in Using the Courts to Protect Vulnerable People: Perspectives from the Judiciary and Legal Profession in Botswana, Malawi, and Zambia, 2014 Southern 
provided that they are independent, well-organized and staffed with welltrained judges and supporting personnel. ${ }^{103}$ The role of courts in the protection of rights of individuals is recognized under the UDHR and the ICCPR. In this regard, Art. 8 of the UDHR states that "everyone has the right to an effective remedy by the competent national tribunals for acts violating the fundamental rights granted to him/her by the constitution or by law". According to Art. 2(3) of the ICCPR:

"each state party to the Convention undertakes to ensure that any person whose rights and freedoms recognized by the Convention are violated shall have an effective remedy and that any person claiming such a remedy shall have the right thereto determined by competent judicial, administrative or legislative authorities or by any other competent authority provided for by the legal system of the state and to develop possibilities of judicial remedies, and to ensure that the competent authorities shall enforce such remedies when granted."

The FDRE Constitution stipulates that all federal and state legislative, executive and judicial organs have the responsibility and duty to respect and enforce human rights and freedoms embodied under Chapter Three ${ }^{104}$ of the Constitution. ${ }^{105}$ These organs are duty-bound to enforce fundamental rights and freedoms recognized under the Constitution "in a manner conforming to the principles of the Universal Declaration of Human Rights, international covenants on human rights and international instruments adopted by Ethiopia". ${ }^{106}$ Moreover, the CRPD -which has been adopted by Ethiopia-

Africa Litigation Centre, Judiciary of Malawi, National Association of Women Judges and Magistrates of Botswana (NAWABO), January 2015, available at http://www.southernafricalitigationcentre.org/1/wp-content/uploads/2014/12/Usingthe-courts-WEB.pdf, accessed on September 30, 2016; See also Esmael Ali Baye, Judicial Enforcement of Human Rights through Regional Economic Communities: A Comparative Analysis with the African Court on Human and Peoples' Rights,' LL.M Thesis, unpublished, School of Law, Addis Ababa University, 2010.

${ }^{103}$ See Andrew K.C. Nyirenda, The Role of the Judiciary in Protecting the Rights of Vulnerable Groups in Malawi, available at http://www.southernafricalitigationcentre.org/1/wp-content/uploads/2014/12/1.pdf, accessed on October 5, 2016.

104 The FDRE Constitution, cited above at note 51, has eleven chapters. Chapter three (Arts. 13-44) is devoted to fundamental rights and freedoms.

105 Id, Art. 13(1) of the FDRE Constitution, cited above at note 51.

${ }^{106}$ In this regard, see: Sisay Alemahu (2008), 'The Justiciability of Human Rights in the Federal Democratic Republic of Ethiopia,' African Human Rights Law Journal, Vol. 8; Tsegaye Regassa (2009), 'Making Legal Sense of Human Rights: The Judicial 
should be applied by Ethiopian courts of all levels, and in effect, they are required to respect and enforce the rights of PWDs including the latter's right of access to justice.

However, the judiciary in Ethiopia is not adequately performing its constitutional mission to protect and enforce fundamental human rights. ${ }^{107}$ Since recent times, however, there are promising judicial trends, particularly in the Cassation Bench of the Federal Supreme Court, which have underscored the judiciary's responsibility to invoke and apply constitutional provisions to protect and enforce fundamental human rights. ${ }^{108}$ No doubt, such trends would also be useful for the implementation of the rights of PWDs, including their right of access to justice in civil proceedings.

\subsection{Major barriers of access to justice for PDWs in federal courts}

\subsubsection{Location and architectural barriers}

Under the CRPD, accessibility is one of the most important cardinal principles. ${ }^{109}$ Accordingly, the Convention states that to enable PWDs to live independently and participate fully in all aspects of life, States Parties have assumed the obligation to take appropriate measures to ensure that PWDs have access (on equal basis with others) to the physical environment, to transportation and communications. The States Parties are also duty-bound, among other things, to identify and eliminate barriers to accessibility to buildings, roads, transportation and other indoor and outdoor services. ${ }^{110}$ Although Ethiopia has assumed this obligation, inaccessibility of the federal courts to PWDs is a formidable barrier to access to justice. The distribution

Role in Protecting Human Rights in Ethiopia,' Mizan Law Review, Vol. 3, No 2 ;

Takele Soboka (2009), 'The Monist-Dualist Divide and the Supremacy Clause:

Revisiting the Status of Human Rights Treaties in Ethiopia,' Journal of Ethiopian

Law, Vol. 23, No 1, pp.132-160.

107 See Sisay Alemahu, cited above at note, 106, pp. 279-284. See also Assefa Fiseha (2010), 'The Concept of Separation of Powers and Its Impact on the Role of the Judiciary', in Assefa Fiseha and Getachew Assefa (editors), Institutionalizing Constitutionalism and Rule of Law: Towards Constitutional Practice in Ethiopia, Ethiopian Constitutional Law Series, Vol.3, pp. 24-26; Yemane Kassa (2015), 'Dealing with Justiciability: In Defense of Judicial Power in Ethiopia,' Mekelle University Law Journal, Vol. 3 No. 1.

${ }^{108}$ See Getachew Assefa (2009), 'Is Publication of a Ratified Treaty a Requirement for Its Enforcement In Ethiopia?: A Comment based on W/t Tsedale Demissie v. Ato Kifle Demissies: Federal Cassation File No. 23632, Journal of Ethiopian Law, Vol. 23, No. 2, pp. 162-170.

${ }^{109}$ Art. 3(1) of the Convention, cited above at note 24.

${ }^{110}$ Id, Art. 9. 
Access to Justice for PWDs in Civil Proceedings before the Federal Courts of Ethiopia ... 23

of the federal courts is not conducive to PWDs as confirmed by the participants of the focus group discussion and judges who filled out questionnaires. ${ }^{111}$ Addis Ababa is a large city, and the local distribution of the courts is not adequate. Moreover, some courts are located at locations that create difficulties of access for PWDs. ${ }^{112}$

Architecturally, buildings should be constructed having in mind the special needs of PWDs. In this regard, Art. 36 the Ethiopian Building Proclamation states that "any building which has a public purpose shall have a means of access to be suitable for use by physically impaired persons, including those who are obliged to use wheelchairs and those who are able to walk but unable to negotiate steps". ${ }^{113}$ Likewise, Art. 34 of the Council of Ministers Building Regulation states that "public buildings or a part thereof shall not prevent the movement of disabled persons". ${ }^{114}$ It is also stated that "suitability for PWDs shall be one criterion to be considered in giving an occupancy permit for partially completed public buildings". ${ }^{115}$ Moreover, the Building Directive ${ }^{116}$ contains very useful provisions relating to the accessibility of buildings for PWDs. ${ }^{17}$ However, most of the courts are not appropriate to PWDs since the buildings are old ${ }^{118}$ having no facilities such as ramps, elevators, adequate lights, toilets and the like ${ }^{119}$ although the newly constructed ${ }^{120}$ buildings have attempted to address accessibility issues, notably ramps and lifts.

${ }^{111}$ Judges who filled out questionnaires. The personal observation of this author is also a living witness of this problem.

112 Telephone Interview with Bisrat Tekilu, Consultant and attorney at law before the federal courts and lecturer at the Ethiopian Civil Service University. Another interviewee (Habtamu Melse) has a similar observation.

${ }^{113}$ Ethiopian Building Proclamation, cited above at note 59.

${ }^{114}$ Building Regulation, cited above at note 62 .

${ }^{115}$ Id, Art. 34(3)

${ }^{116}$ Building Directive, cited above at note 64 .

117 Ibid.

118 The fact that most of the buildings used by the federal courts are rented buildings from third parties has compounded the problem of accessibility since the owners of the buildings are not concerned with accessibility issue by PWDs at the time of construction. Others are old buildings that do not address the accessibility problems faced by PWDs.

119 Personal observation of the author.

120 The new buildings constructed in Yeka, Kera and Lideta areas are good examples in this regard. 


\subsubsection{Absence of training}

Article 8(1) of the CRPD stipulates that "States Parties to the Convention undertake to adopt immediate, effective and appropriate measures to raise awareness throughout society including at the family level, regarding the rights of PWDs, and to foster for the rights and dignity of PWDs." In particular, Art. 13(2) of the Convention requires states parties to "promote appropriate training for those working in the field of administration of justice with a view to helping to ensure effective access to justice for PWDs."

However, due attention has not been given to this national responsibility which should have been fulfilled by providing training to the judges and other support staff. For example, the Second Growth and Transformation Plan (GTP II), ${ }^{121}$ which has now expired, provided that "the key issue in strengthening the justice system is institutional capacity building and particularly strengthening the organizational structure with trained manpower." It had envisaged a series of institutionalized training programs that would enhance attitudinal change, integrity, commitment, knowledge and skill. ${ }^{122}$ However, the document did not address training on the rights of PWDs including their access to justice.

Responses of judges in questionnaires revealed that training on access to justice has been lacking in the federal courts during the implementation period of GTP II (2016-2020). Almost all the judges who filled the questionnaires concluded that training is extremely necessary to understand the rights of PWDs in general and the right of access to justice in particular. Furthermore, the performance reports of the Federal Supreme Court ${ }^{123}$ reveal that meaningful trainings have never been given to judges and the support staff regarding the right of PWDs to access to justice. ${ }^{124}$

121 Currently, the Federal Government of Ethiopia has formulated a draft ten years national plan, which is expected to be a successor of the GTP II. The Draft National Plan has addresses various economic, social and political issues. However, PWDs have been mentioned very briefly (p. 121). See also:

https://www.fanabc.com/english/ethiopia-unveils-its-10-year-development-plan/.

${ }^{122}$ Federal Democratic Republic of Ethiopia Growth and Transformation Plan II (GTP II) $(2015 / 16-2019 / 20)$, available at

http://dagethiopia.org/new//docstation/com_content.article/100/gtpii_english_transl ation_final_june_21_2016.pdf, accessed on September 20, 2016, p. 202.

123 See for instance, The 2011 E.C Budget Year Federal Courts Performance Report, Federal Supreme Court, Nehase 2011 E.C (in Amharic), pp. 6-10.

${ }^{124}$ See for instance, The 2011 E.C Budget Year Federal Courts Annual Plan, Federal Supreme Court, Hamle 2010 E. C (in Amharic), p. 23. 
Access to Justice for PWDs in Civil Proceedings before the Federal Courts of Ethiopia ... 25

\subsubsection{Unconducive courtrooms}

The right of access to justice cannot be realized meaningfully in the absence of conducive courtrooms. However, the courtrooms in the federal courts are not generally conducive to PWDs; ${ }^{125}$ and, many courtrooms do not have chairs and tables which may be used by persons with physical impairments. This fact was fully supported by almost all the judges who filled out questionnaires. Individuals who participated during the focus group discussion (who have exposures to the federal courts) stated that most of the courtrooms are not suitable to PWDs.

\subsubsection{Attitudinal problems}

Various studies show that attitudinal problem is an impediment in the protection of the rights of PWDs. ${ }^{126}$ Participants of the focus groups discussions stated that judges of the federal courts do not seem to know the special legal protection for PWDs that are enshrined in international legal instruments and the Ethiopian laws. They noted that judges generally treat PWDs kindly not because they (the judges) know that doing so is their legal obligation but out of sense of charity. On the other hand, the participants underscored that the non-judicial staff at the courts are in most cases indifferent to the special needs of PWDs; and most court employees) treat PWDs exactly in the same manner as other persons. According to the participants, there are persons who tend to mistreat PWDs when the latter request various services (such as the location of courtrooms, date of court appointments, and copies of judgments). The participants, in general, underlined the importance of enhancing positive attitudes towards PWDs by giving training and creating awareness.

125 Personal observations of the author.

126 See: Almaz Getachew (2011), Attitudes of Ethiopian College Students toward People with Visible Disabilities, PhD (Doctor of Philosophy) thesis, University of Iowa; Mapuranga Barbra and Phillipa Mutswanga (2014), 'The Attitudes of Employers and Co-Workers towards the Employment of Persons with Disabilities in Zimbabwe,' International Journal on Managerial Studies and Research (IJMSR), Vol. 2, Issue 3, pp. 7-19; Denise Thompson, Karen R Fisher, Christiane Purcal, Chris Deeming and Pooja Sawrikar, Community Attitudes to People with Disability: scoping project, Occasional Paper No. 39, Social Policy Research Centre, Disability Studies and Research Centre, University of New South Wales, Commonwealth of Australia, 2011, available at:

http://www.melbourneinstitute.com/downloads/hilda/Bibliography/Other_Publicatio ns/2013/Thompson_etal_community_attitu 


\subsubsection{Gaps in the usage of ICT}

There are various information communication technologies that cater for the special needs of PWDs, including access to justice in civil and criminal proceedings. To this end, different countries have been using technologies for the deaf and hard of hearing, the blind and for persons with mental disabilities. ${ }^{127}$ The CRPD states the importance of usage of ICT to enhance the right to access to justice for PWDs. To this end, the CPRD stipulates that:

state parties to the Convention have the duty to make sure accessibility through, inter alia, promoting access for PWDs to new information and communications technologies and systems, including the Internet and promoting the design, development, production and distribution of accessible information and communications technologies and systems at an early stage, so that these technologies and systems become accessible at minimum cost. ${ }^{128}$

Although Ethiopia does not have a law that obliges courts to use appropriate technologies to ensure the right of access to justice for PWDs in civil proceedings, GTP II had pledged to improve access to justice and render efficient and effective justice services by supporting the judiciary with modern information and communication technology. It had promised that plasma, mobile and fixed judiciary hearing sites would be further expanded and strengthened to enhance access to justice in general. ${ }^{129}$ However, this was too general and it did not make reference to the special needs of PWDs with regard to access to justice.

In addition to this general policy document, the Federal Courts Strategic Plan (2008 E.C- 2012 E.C, i.e. 2015/16 - 2019/20) underscored that modern communication technology would be used to enhance access to justice of the general public and PWDs in particular. ${ }^{130}$ However, the document did not contain sufficient details on how and to what extent the special needs of PWDs would be addressed by various technologies during the strategic plan

${ }^{127}$ Deepti Samant Raja, Bridging the Disability Divide through Digital Technologies, Background Paper for the 2016 World Development Report: Digital Dividends, World Development Report, 2016, available at http://pubdocs.worldbank.org/en/123481461249337484/WDR16-BP-Bridging-theDisability-Divide-through-Digital-Technology

${ }^{128}$ Art. 9 (2)(g \&h)

${ }^{129}$ GTP II, cited above at note 92, p. 202.

130 See the Federal Courts Strategic Plan, 2008-2012 E.C, 2008 E.C (i.e. 2015/16 2019/20, unpublished, on file with author in soft copy. 
Access to Justice for PWDs in Civil Proceedings before the Federal Courts of Ethiopia ... 27

period. ${ }^{131}$ It is to be noted that the promises in these documents have largely remained unfulfilled since no meaningful measures were taken as attested by the responses from judges, an ICT official ${ }^{132}$ and participants of focus group discussion. ${ }^{133}$ To date, the use of ICT to enhance the access of PWDs to civil justice has not been realized. ${ }^{134}$

\subsubsection{Lack of sign language interpreter}

The right of access to justice for persons with hearing impairments, inter alia, requires sign language interpreters who would facilitate communication in court proceedings. ${ }^{135}$ The right to get sign language interpreter in court proceedings is a right recognized under the CRPD, ${ }^{136}$ since it is not possible to talk about access to justice for persons with hearing impairments in the absence of sign language interpreters. Despite this international obligation, the federal courts of Ethiopia have gaps in this regard as it was confirmed by the responses of all the judges who filled out the questionnaires, interviewees and participants in the focus group discussion. This author has also observed the general gaps in qualified interpreters, and absence of sign language interpreters.

\subsubsection{Cost of litigation as a barrier to access to justice}

Cost incurred by parties to a civil proceeding are court fees, attorney's fees, stamp duties (where documents are annexed as evidence), stationery expenses, translation expenses and the like. Attorney fees and court fees can

131 Ibid

132 Interview with Mr. Eniyew Gashaw, Network and Security Team Leader, Federal High Court, October 31, 2016. Even today, the problem is not resolved, as stated in a recent interview with Ato Tarekegn Damessa, public prosecutor.

133 The author of this article has also observed that the special interests of PWDs, as far as access to civil justice is concerned, have not been served by ICT in the federal courts although there have been very modest attempts of using ICT in courts as indicated in the annual plans and performance reports of the federal courts prepared by the Federal Supreme Court.

${ }^{134}$ Telephone Interview with Samuel Ephrem, consultant and attorney at law.

135 To understand the implementation of this right in American states, see Laura L. Rovner (1992), 'Right to Be Heard: The Obligation of State Courts to Pay for Interpreters for Deaf Litigants', Cornell Journal of Law and Public Policy, Vol. 2, Issue 1. See also Ruth Morris, The Face of Justice: Historical Aspects of Court Interpreting, Bar-Ilan University, Ramat-Gan, Israel, available at: http://www.ruth-morris.info/wp-content/uploads/2010/03/Historical-Aspects-ofCourt-InterpretingFINAL1.pdf, accessed on September 20, 2016.

${ }^{136}$ CRPD, cited above at note 24, Art. 9(2)(e). 
indeed be very cumbersome to indigent persons in general and indigent PWDs in particular. ${ }^{137}$ As PWDs are disadvantaged in terms of employment, access to resources, information and various opportunities in material possessions, the access to justice for PWDs can be hindered by court fees and attorney fees. ${ }^{138}$

Although the Civil Procedure Code contains some provisions which allow filing civil suits in forma paupris, the procedure is relatively cumbersome to PWDs ${ }^{139}$ thereby adversely affecting access to justice for PWDs. Indeed, the pro bono service rendered by federal advocates is of some help ${ }^{140}$ as advocates are required to render pro bono services by the Federal Courts Advocates' Code of Conduct Regulation. ${ }^{141}$ Although the Regulation does not make express reference to PWDs, they can invoke it to get pro bono advocacy services. They can do this by applying to the relevant department of the Federal Attorney General Office; or they may apply to the court in which their case is filed since the court may request the Office of the Federal Attorney General to assign an advocate to the indigent applicant. ${ }^{142}$ They can also approach their respective associations ${ }^{143}$ so that the latter may

${ }^{137}$ Art. 215 of the Civil Procedure Code, cited above at note 84 .

${ }^{138}$ See David Allen Larson, Access to Justice for Persons with Disabilities: An Emerging Strategy, Laws 2014, Vol.3, ISSN 2075-471X, OPEN ACCESS, available at www.mdpi.com/2075-471X/3/2/220/pdf

${ }^{139}$ See the Civil Procedure Code, cited above at note 84, Arts. 467-479.

${ }^{140}$ Interviews with an employee working at the Federal High Court of Ethiopia, January 23, 2017.

${ }^{141}$ See Federal Court Advocates' Code of Conduct Regulations, Reg. No 57/1999, Fed. Neg. Gaz., Year 6, No 1. In this regard, Art. 49 of the Regulation states that any advocate shall render fifty hours of legal service in a year, free of charge or upon minimum payment to persons who cannot afford to pay, charity organizations, community institutions, civil organizations, persons to whom court requests legal service and committees and institutions that work for improving the law, the legal profession and the justice system.

${ }^{142}$ However, this requires awareness on the part of PWDs that they can get advocacy services from advocates through the request of the court.

${ }^{143}$ Persons with disabilities have formed six national associations under the umbrella of a Federation. These are: Federation of Ethiopian National Associations of Persons with Disabilities, (FENAPD), Ethiopian National Association of the Blind, Ethiopian National Association of the Physically Handicapped, Ethiopian National Association of the Deaf, Ethiopian National Association of the Blind-Deaf, Ethiopian National Association of Persons Affected by Leprosy, Ethiopian National Association on Intellectual Disability. Other disability associations playing a key role in the disability equality movement are: Ethiopian National Disability Action Network (ENDAN), Ethiopian Women with Disabilities National Association, Tigray 
Access to Justice for PWDs in Civil Proceedings before the Federal Courts of Ethiopia ... 29

request the Attorney General Office to deploy free advocacy service by assigning an advocate. ${ }^{144}$

\section{Concluding Remarks}

Ethiopia signed the CRPD on the $30^{\text {th }}$ March 2007 and ratified it on July 7, 2010. With a view to implementing the Convention Ethiopia has taken certain measures. With regard to access to justice of PWDs in civil proceedings, however, there are no adequate normative and institutional frameworks that would be instrumental to implement the right of access to justice for PWDs before the federal courts.

The 1995 FDRE Constitution does not contain detailed provisions dealing with the substantive and procedural rights of PWDs although Art. 37 is generally applicable to the right of access to justice. Moreover, the 1965 Civil Procedure Code does not have legal provisions that would address the special needs of PWDs at all stages of the civil proceeding. Nor has the country enacted other procedural law that would enhance access to justice for PWDs in civil proceedings.

As indicated above, the local distribution of the court premises is not suitable to PWDS. Even when PWDs somehow reach at courts, the premises have architectural problems. Judges of the federal courts have not also been adequately trained with regard to the rights of PWDs in general and the latter's right of access to justice in particular, thereby causing inadequate knowledge and awareness (on the part of judges) and resulting in attitudinal problems towards PWDs. In the course of conducting this study, it has been understood that courtrooms are not conducive to PWDs; proper ICTs which help to ensure access to justice of PWDS are not used; and sign language interpreters for persons with hearing problems are not available. The other problems which hinder access to justice in civil proceedings are cost of proceedings, delay of civil cases, absence of legal literacy and of legal counsel in civil proceedings.

In view of the above problems, it is high time for the government of Ethiopia to take some legislative and institutional measures. To begin with,

Disabled Veterans Association and The Ethiopian Centre for Disability and Development (ECDD). The list is available at:

http://www.ilo.org/wcmsp5/groups/public/@ed_emp/@ifp_skills/documents/publica tion/wcms_112299.pdf

144 Participants of the focus group discussion asserted that this service is underutilized because of gaps in awareness on the part of PWDs. 
(at least in the long run) the FDRE Constitution should be amended with a view to incorporating both substantive and procedural rights (including the right of access to justice) of PWDs with some detail. On the other hand, because amending the FDRE Constitution is not an easy task under the Ethiopian political atmosphere at least in the short run, the Ethiopian lawmaker has to come up with a comprehensive proclamation dealing with the substantive and procedural rights of PWDs including their right of access to justice.

Meanwhile, trainings should be given to the relevant duty bearers with due attention to the need to interpret the existing provisions of the FDRE Constitution in light of the spirit of the provisions of the CRPD since such approach is constitutionally dictated under Art. 13(2) of the FDRE Constitution. Secondly, the 1965 Civil Procedure Code should be amended and disability friendly provisions should be included. If amending the Code is impossible in the near future, the lawmaker should address issues pertaining to access to justice for PWDs through a proclamation. In case the Parliament fails to issue such a proclamation in the foreseeable future, the Federal Supreme Court should issue a procedural bench book (and effectively distribute it to courts at all levels) which would address the special needs of PWDs in civil proceedings.

Moreover, modern communication technologies, to the extent the capacity of the nation permits, should be put in place in courtrooms taking into consideration the needs of PWDs in civil proceedings. The courts should deploy sign language interpreters for those who have hearing impairments. The Federal Supreme Court should also give adequate training to the judges and its support staff of all levels regarding the rights of PWDs (in general and their right of access to justice in particular) that are recognized under international and national legal instruments; and it has to ensure access to information for PWDs so that they can be duly informed of court orders, decisions and directives.

In order to minimize the negative impact of litigation cost relating to access to justice, there should be concerted efforts to raise the awareness of PWDs so that the latter can make use of the provisions the Civil Procedure Code that deal with suit in forma pauperis. The pro bono services of advocates should also be adequately available to PWDs under the strict supervision of the Office of the Federal Attorney General. 